\title{
Qualitative identification of growth hormone-releasing hormones in human plasma by means of immunoaffinity purification and LC-HRMS/MS
}

\author{
Andre Knoop ${ }^{1} \cdot$ Andreas Thomas $^{1} \cdot$ Eric Fichant $^{2} \cdot$ Philippe Delahaut $^{2}$. \\ Wilhelm Schänzer ${ }^{1}$ • Mario Thevis ${ }^{1,3}$
}

Received: 14 December 2015 /Revised: 18 January 2016 / Accepted: 28 January 2016/Published online: 15 February 2016

(C) The Author(s) 2016. This article is published with open access at Springerlink.com

\begin{abstract}
The use of growth hormone-releasing hormones (GHRHs) is prohibited in sports according to the regulations of the World Anti-Doping Agency (WADA). The aim of the present study was to develop a method for the simultaneous detection of four different GHRHs and respective metabolites from human plasma by means of immunoaffinity purification and subsequent nano-ultrahigh performance liquid chromatography-high resolution/high accuracy (tandem) mass spectrometry. The target analytes included Geref (Sermorelin), CJC-1293, CJC-1295, and Egrifta (Tesamorelin) as well as two metabolites of Geref and CJC1293, which were captured from plasma samples using a polyclonal GHRH antibody in concert with protein A/G monolithic MSIA ${ }^{\mathrm{TM}}$ D.A.R.T.'S ${ }^{\circledR}$ (Disposable Automation Research Tips) prior to separation and detection. The method was fully validated and found to be fit for purpose considering the parameters specificity, linearity, recovery (19-37\%), lower limit of detection $(<50 \mathrm{pg} / \mathrm{mL})$, imprecision $(<20 \%)$, and ion suppression/enhancement effects. The analytes' stability and metabolism were elucidated using in vitro and in vivo approaches. EDTA blood samples were collected from rats 2, 4 , and $8 \mathrm{~h}$ after intravenous administration of GHRH (one compound per test animal). All intact substances were
\end{abstract}

Mario Thevis

thevis@dshs-koeln.de

1 Institute for Biochemistry-Center for Preventive Doping Research, German Sport University Cologne, Am Sportpark Müngersdorf 6, 50933 Cologne, Germany

2 Laboratoire d'Hormonologie, C.E.R. Groupe-Département Santé, Rue du Point du jour 8, 6900 Marloie, Belgium

3 European Monitoring Center for Emerging Doping Agents (EuMoCEDA), Cologne/Bonn, Germany detected for at least $4 \mathrm{~h}$ but no anticipated metabolite was confirmed in laboratory rodents' samples; conversely, a Geref metabolite $\left(\mathrm{GHRH}_{3-29}\right)$ was found in a human plasma sample collected after subcutaneous injection of the drug to a healthy male volunteer. The obtained results demonstrate that GHRHs are successfully detected in plasma using an immunoaffinity-mass spectrometry-based method, which can be applied to sports drug testing samples. Further studies are however required and warranted to account for potential species-related differences in metabolism and elimination of the target analytes

Keywords LC-HRMS/MS · GHRH · Immunoaffinity · Doping $\cdot$ MSIA $^{\text {TM}}-$ Tips

\section{Introduction}

Growth hormone-releasing hormones (GHRHs) are hypothalamic peptides stimulating the endogenous growth hormone (GH) secretion which, in turn, can entail anabolic effects [1]. Due to their presumed performance enhancing effects for athletes, the World Anti-Doping Agency (WADA) has banned $\mathrm{GH}$ and its releasing factors such as GHRH and analogues from sports [2]. As early as 1984, Ling et al. [3] recognized that the human growth hormone-releasing factor hGRF $_{1-44}$ amide) can be degraded to $\mathrm{hRRF}_{1-29}$ amide (Sermorelin) without decreasing its bioactivity to less than $50 \%$. Various recombinant and synthetic analogues with reduced and also modified amino acid sequences for better metabolic resistance have been investigated, verifying their endocrine effects [4-11]. These studies focused, among other aspects, on identifying metabolic reactions and degradation processes of the truncated and modified analogues of GHRH and specifically determined the protective properties of the introduced 
D-amino acid moieties against unspecific degradations of the therapeutic peptides in plasma [7]. Further, different confiscated products have corroborated suspicions of a growing GHRH black market and illicit synthesis of analogue peptide hormones. For instance, CJC-1295 ((D-Ala ${ }^{2}, \mathrm{Gln}^{8}, \mathrm{Ala}^{15}$, $\mathrm{Leu}^{27}$ )-GRF amide), an emerging drug candidate, was identified in 2010 [12], and in 2014 the finding of a modified analogue of human growth hormone-releasing hormone $\left(\mathrm{hGHRH}_{1-44}\right)$ was reported [13].

For sports drug testing purposes, the prediction and characterization of the metabolic behavior of particularly peptidederived substances as well as analytical approaches allowing for appropriately sensitive detection methods are vital. Therefore, four different peptidic compounds with GHreleasing properties exhibiting molecular masses between 3355 and $5132 \mathrm{kDa}$ were intravenously administered to rats, and blood and plasma samples were collected. In addition, a healthy male volunteer received a single subcutaneous dose of Sermorelin and EDTA blood specimens were sampled. All specimens were subjected to established principles of immunoaffinity purification [14-16] followed by nano-ultra high performance liquid chromatography (UHPLC) coupled to high resolution tandem mass spectrometry (HRMS/MS) [17-20]. However, in the present approach, an alternative methodology utilizing an immunoaffinity extraction protocol based on pipette tips containing covalently immobilized recombinant Protein A/G [21] combined with a polyclonal anti-GHRH antibody was employed. Here, besides the aforementioned intact peptidic substances, two synthetic metabolites (degradation products) were included into the test method. For Sermorelin, an in vitro-derived metabolite has been described as originating from the loss of the N-terminal TyrAla-residue due to cleavage by dipeptidyl peptidase-IV (DPPIV) [7]. For CJC-1293, it was anticipated that N-terminal Tyrresidue will also be enzymatically removed [7, 22].

\section{Material and methods}

\section{Chemicals and materials}

For all aqueous buffers and diluting steps, ultrapure water obtained from a MilliQ device was used. Glacial acetic acid was purchased from Merck (Darmstadt, Germany). Phosphate-buffered saline (PBS, pH 7.4) tablets were obtained from Sigma (Schnelldorf, Germany) and used for preparation of PBS buffer according to the manufacturer's recommendations (one tablet dissolved in $200 \mathrm{~mL}$ of water). The Finnpipette ${ }^{\mathrm{TM}}$ Novus i Multichannel Electronic Pipette (including adjustable pipetter stand) and the appropriate Protein A/G MSIATM D.A.R.T.'S ${ }^{\circledR}$ (96 tips) were obtained from Thermo (San Diego, CA, USA). Corresponding 96-well plates $(0.5 \mathrm{~mL}$, polypropylene) were purchased from Agilent
Technologies (Waldbronn, Germany). GHRH primary antibody (polyclonal; host, rabbit) was kindly provided from C.E.R.-Groupe Laboratories (Marloie, Belgium). Commercially available pooled human plasma (Octaplas, for intravenous infusion) was purchased from Octapharma (Langenfeld, Germany). The internal standard (ISTD) acetyl-(Tyr $\left.{ }^{1}, \mathrm{D}-\mathrm{Arg}^{2}\right)-\mathrm{GRF}_{1-29}$ amide and Tesamorelin (Egrifta ${ }^{\mathrm{TM}}$ ) were obtained from Bachem (Bubendorf, Switzerland). GHRH $_{1-29}$ (hGRF, Geref, Sermorelin) was purchased from the Biologisch-Medizinisches Forschungszentrums (Düsseldorf, Germany). CJC-1295 ((D$\mathrm{Ala}^{2}, \mathrm{Gln}^{8}, \mathrm{Ala}^{15}, \mathrm{Leu}^{27}$ )-GRF amide) and CJC-1293 ((D$\mathrm{Ala}^{2}$ )-GRF amide) were custom-synthesized by Centic Biotec (Jena, Germany), and the metabolites of Sermorelin $\left(\mathrm{GRF}_{3-29}\right)$ and CJC-1293 ((D-Ala $\left.{ }^{2}\right)-\mathrm{GRF}_{2-29}$ amide) were by the Medizinisch-Naturwissenschaftliches Forschungszentrum (Eberhard Karls University, Tübingen, Germany).

\section{Liquid chromatography (LC)}

LC separation was accomplished on an AQUITY nanoflow UHPLC system from Waters (Milford, CT, USA) equipped with a Waters Symmetry trapping column (C18, $180 \mu \mathrm{m} \times 20 \mathrm{~mm}, 5 \mu \mathrm{m}$ particle size) and a New Objective PicoChip Reprosil pur (C18, $75 \mu \mathrm{m}, 100 \mathrm{~mm}, 3 \mu \mathrm{m}$ particle size) as analytical column and emitter. For gradient elution, $0.1 \%$ formic acid was used as solvent $\mathrm{A}$ and acetonitrile acidified with $0.1 \%$ formic acid as solvent $\mathrm{B}$. The trapping of $1 \mu \mathrm{L}$ of sample solution was performed using $1 \%$ B for $3 \mathrm{~min}$ with a flow of $8 \mu \mathrm{L} / \mathrm{min}$. The gradient program for the analytical run, conducted at a flow rate of $350 \mathrm{~nL} / \mathrm{min}$, started with $1 \% \mathrm{~B}$, increasing to $60 \% \mathrm{~B}$ within $20 \mathrm{~min}$ and to $80 \% \mathrm{~B}$ in 2 min. Subsequent re-equilibration at $1 \% \mathrm{~B}$ was accomplished within 8 min.

\section{Mass spectrometry}

For the mass spectrometric detection, a Q Exactive (Thermo, Bremen, Germany) operating in positive ion mode equipped with a nano electrospray ionization source (+ESI) was employed. Ionization was accomplished at a transfer capillary temperature of $150^{\circ} \mathrm{C}$ and a spray voltage of $2 \mathrm{kV}$. Data was generated in full scan mode $(\mathrm{m} / \mathrm{z} 400-1500$, resolution 35,000 full width at half maximum (FWHM)) and targeted selected ion monitoring (tSIM, resolution 17,500 FWHM), which were multiplexed four times and combined with an inclusion list containing accurate $\mathrm{m} / \mathrm{z}$ values of most abundant charge states of all target peptides. The isolation window of the quadrupole was set to $3 \mathrm{~m} / \mathrm{z}$ for the tSIM and $1.5 \mathrm{~m} / \mathrm{z}$ for data-dependent tandem mass spectrometry ( $\left(\mathrm{ddMS}^{2}\right)$ experiments, respectively. Accurate mass measurements $(<5 \mathrm{ppm})$ were ensured through calibration according to manufacturer's recommendations (calibration mixture of caffeine, tetrapeptide MRFA, and 
Ultramark). The gas supply consisted of nitrogen produced by a nitrogen generator (CMC Instruments $\mathrm{GmbH}$, Eschborn, Germany). Main mass spectrometric parameters and data of the target analytes are shown in Table 1.

\section{Sample preparation and purification-MSIA ${ }^{\text {TM}}-$ Tips}

Sample aliquots of $100 \mu \mathrm{L}$ of plasma were spiked with $1 \mu \mathrm{L}$ of ISTD [200 ng/mL] and diluted with $100 \mu \mathrm{L}$ of PBS before extraction. The multichannel pipette was equipped with up to 12 protein A/G MSIATM_Tips and up to 2000 cycles (one cycle corresponding to one round of liquid aspiration and ejection) were used for distinct sample preparation steps as outlined in Table 2. First, tips were conditioned with PBS before binding $10 \mu \mathrm{g}$ of the polyclonal GHRH primary antibody $(5 \mu \mathrm{L}[2 \mathrm{mg} / \mathrm{mL}]$ in $95 \mu \mathrm{L}$ PBS $)$ to the proteins $A / G$ immobilized on the monolithic adsorbent surface. After washing with PBS to remove unbound antibody residues the target analytes were extracted from plasma by antibody-antigen complex formation prior to three consecutive washing steps with PBS and water (Table 2). The peptides of interest were eluted into LoBind tubes using $3 \%$ of aqueous acetic acid and the eluate was immediately used for injection into the UHPLC-MS(/MS) system. In Fig. 1, a schematic illustration of the relevant principle steps of the MSIA $^{\mathrm{TM}}$ purification is presented.

\section{Qualitative method validation}

For qualitative result interpretation, the developed method was validated for human plasma regarding the following parameters: specificity, linearity, recovery, lower limit of detection (LLOD), imprecision, and ion suppression/ enhancement effects.

In order to identify potential interfering signals and mean background noise, ten blank plasma specimens (five female and five male) from healthy volunteers without any known medications were prepared as described above to ensure specificity of signals at expected retention times $(n=5+5)$. For the evaluation of the assay's linearity, a mixture containing reference standards of all target analytes was spiked at six concentration levels $(0,0.1,0.2,0.4,1,2$, and $5 \mathrm{ng} / \mathrm{mL}$ of each analyte) into blank plasma specimens, which were analyzed as outlined above. The extraction recovery was determined by using 12 plasma aliquots containing $1 \mathrm{ng} / \mathrm{mL}$ per analyte. The first set of six samples was fortified before immunoaffinity purification and the other six were spiked after workup and immediately before LC-MS/MS analysis $(n=6+6)$. The LLOD was evaluated as the lowest content measurable via signal-to-noise ratio $(\mathrm{S} / \mathrm{N})$ of $>3$ and therefore six biological replicates were prepared and analyzed at the estimated LLOD of $50 \mathrm{pg} / \mathrm{mL}$. To calculate the method's imprecision, six sample replicates at three different concentrations $(0.05,1$, and $5 \mathrm{ng} /$ $\mathrm{mL})$ were analyzed $(n=3 \times 6)$ as before. For reasons of matrix effects and influences on ionization (ion suppression or enhancement), peak areas of blank plasma aliquots spiked after sample workup [0.5 ng/mL per analyte] were compared to those of an analogously fortified neat solution (3\% acetic acid).

\section{In vitro experiments}

For the investigation of the metabolic fate of GHRHs, in vitro experiments using fresh human plasma samples were conducted, allowing to test for potential degradation products of the studied substances. In accordance to earlier reported methods [23], aliquots of human plasma samples were diluted (1:1) with PBS [22] and spiked to $10 \mu \mathrm{g} / \mathrm{mL}$ with Sermorelin or Tesamorelin, respectively. After incubation for 30, 60, 120, and $240 \mathrm{~min}$ at $37^{\circ} \mathrm{C}$, samples were prepared and analyzed as described elsewhere [20]. Simulating degradation processes of exopeptidases, potential metabolites were considered by eliminating up to three amino acids from both $N$ - and $C$-terminus. All samples were probed for the anticipated metabolic products as well as for the corresponding intact drugs.

Table 1 Amino acid sequences and mass spectrometric parameters of target analytes

\begin{tabular}{|c|c|c|c|c|c|}
\hline Peptide & Amino acid sequence & $\begin{array}{l}\text { Monoisotopic } \\
\text { mass }[\mathrm{Da}]\end{array}$ & $\begin{array}{l}\text { Precursor } \\
{[\mathrm{m} / \mathrm{z}]}\end{array}$ & $\begin{array}{l}\text { Predominant } \\
\text { charge state }\end{array}$ & $\begin{array}{l}\text { Retention } \\
\text { time [min] }\end{array}$ \\
\hline Sermorelin & YADAIFTNSYRKVLGQLSARKLLQDIMSR-NH ${ }_{2}$ & 3355.8 & 672 & $5+$ & 19.6 \\
\hline $\begin{array}{l}\text { Sermorelin } \\
\text { metabolite }\end{array}$ & DAIFTNSYRKVLGQLSARKLLQDIMSR-NH ${ }_{2}$ & 3121.8 & 625 & $5+$ & 19.5 \\
\hline CJC-1293 & YdADAIFTNSYRKVLGQLSARKLLQDIMSR-NH ${ }_{2}$ & 3355.8 & 672 & $5+$ & 19.6 \\
\hline $\begin{array}{l}\text { CJC-1293 } \\
\text { metabolite }\end{array}$ & dADAIFTNSYRKVLGQLSARKLLQDIMSR-NH ${ }_{2}$ & 3192.8 & 639 & $5+$ & 19.4 \\
\hline CJC-1295 & YdADAIFTQSYRKVLAQLSARKLLQDILSR-NH ${ }_{2}$ & 3365.9 & 674 & $5+$ & 19.8 \\
\hline Tesamorelin & $\begin{array}{l}\text { hexenoyl-YADAIFTNSYRKVLGQLSARKLLQDIMSR } \\
\text { QQGESNQERGARARL-NH }\end{array}$ & 5132.7 & 734 & $7+$ & 19.7 \\
\hline ISTD & acetyl-YRDAIFTNSYRKVLGQLSARKLLQDIMSR-NH ${ }_{2}$ & 3482.9 & 697 & $5+$ & 19.6 \\
\hline
\end{tabular}


Table 2 Pipetting scheme for GHRH purification using a Thermo Finnpipette ${ }^{\mathrm{TM}}$ Novus i Multichannel Electronic Pipette equipped with Protein A/G MSIA ${ }^{\text {TM}}-$ Tips

\begin{tabular}{|c|c|c|c|c|c|c|c|c|}
\hline Step & $\begin{array}{l}1 \\
\text { Wash }\end{array}$ & $\begin{array}{l}2 \\
\text { Antibody load }\end{array}$ & $\begin{array}{l}3 \\
\text { Wash }\end{array}$ & $\begin{array}{l}4 \\
\text { Antigen binding }\end{array}$ & $\begin{array}{l}5 \\
\text { Wash }\end{array}$ & $\begin{array}{l}6 \\
\text { Wash }\end{array}$ & $\begin{array}{l}7 \\
\text { Wash }\end{array}$ & $\begin{array}{l}8 \\
\text { Elution }\end{array}$ \\
\hline Liquid & PBS & $\begin{array}{l}\text { AB dissolved in } \\
\text { PBS }[10 \mu \mathrm{g} / \mathrm{mL}]\end{array}$ & PBS & Plasma sample & PBS & PBS & Water & $\begin{array}{c}3 \% \text { acetic } \\
\text { acid }\end{array}$ \\
\hline Cycles & 10 & 999 & 10 & $2 \times 999$ & 10 & 10 & 10 & 200 \\
\hline Cycle volume $[\mu \mathrm{L}]$ & 150 & 75 & 150 & 150 & 150 & 150 & 150 & 75 \\
\hline Total volume $[\mu \mathrm{L}]$ & 300 & 100 & 300 & 200 & 300 & 300 & 300 & 100 \\
\hline
\end{tabular}

\section{Administration studies}

\section{Rat administration studies}

To probe for the in vivo metabolism of Sermorelin, CJC-1293, CJC-1295, and Tesamorelin, $0.1 \mathrm{mg}$ of each GHRH was administered intravenously to three rats (Rattus norvegicus, Wistar, 200-300 g bodyweight at dosing). Urine samples were collected in a metabolic cage prior to and $6,12,24$, and $30 \mathrm{~h}$ after administration but not subjected to analysis in this study. Blood was sampled at 2, 4, and $8 \mathrm{~h}$ after injection and specimens were centrifuged at $13,000 \times \mathrm{g}$ for $20 \mathrm{~min}$ to produce serum or EDTA plasma, which was stored at $-20{ }^{\circ} \mathrm{C}$ until analysis. The animal studies were conducted with approval of the respective ethical committee and the laboratory followed the directive 2010/63/EU of the European parliament and the council of 22 September 2010 on the protection of animals used for scientific purposes.

\section{Human urine and plasma samples}

Complementary to the aforementioned rat elimination study, a single dose of $500 \mu \mathrm{g}$ of Geref (Sermorelin) (Hallandale Pharmacy, FL, USA) was self-administered subcutaneously by a healthy male volunteer (59 years, $78 \mathrm{~kg}$ ) following the provision of written consent. EDTA plasma samples were collected 30, 90, and $270 \mathrm{~min}$ after dosing and the specimens were stored at $-20{ }^{\circ} \mathrm{C}$ until analysis.

\section{Results and discussion}

All of the herein investigated peptides represent substances that are prohibited at all times according to regulations established by the WADA [2]. To date, information concerning their metabolism and potential windows of detection in a doping control context has been scarce;

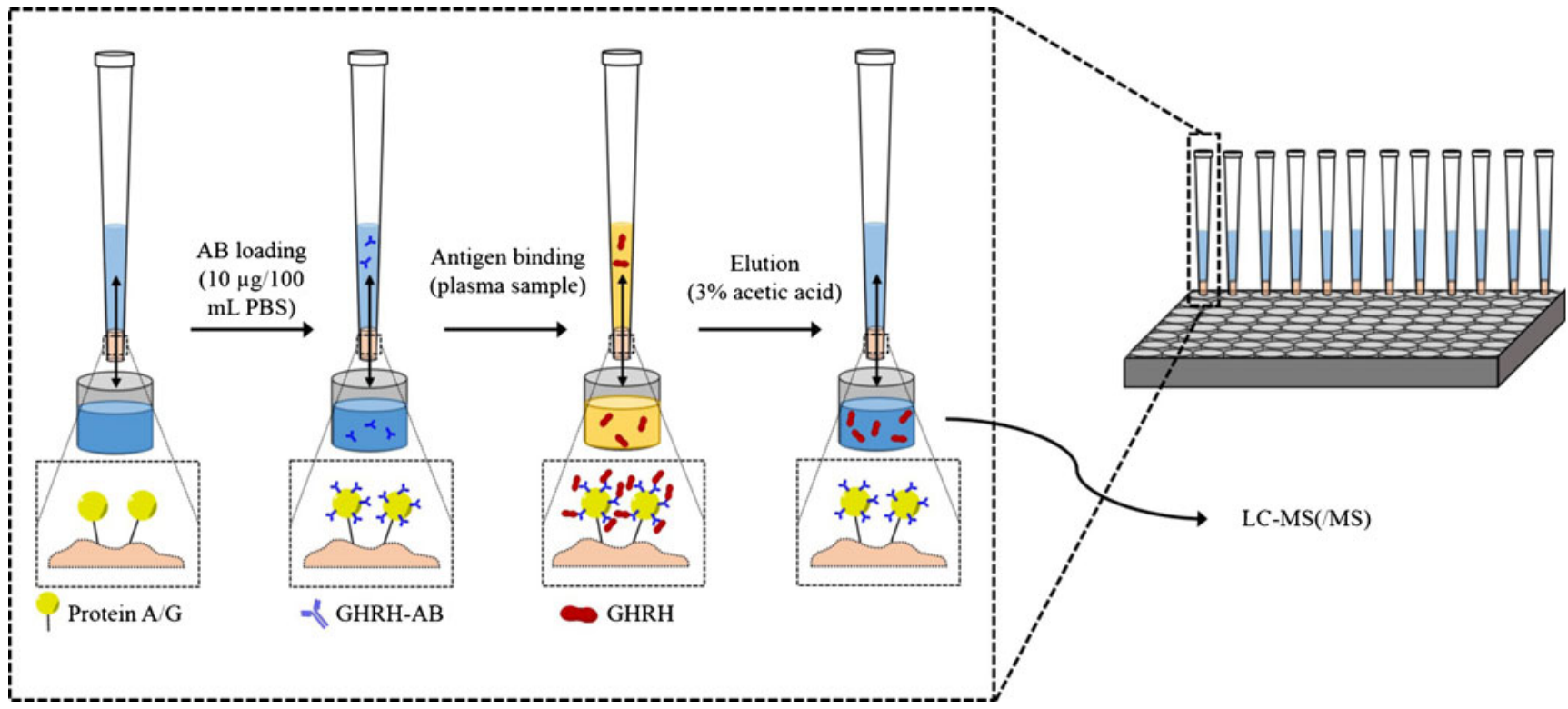

Fig. 1 Sample preparation procedure and main steps of MSIA ${ }^{\mathrm{TM}}$ purification using protein $\mathrm{A} / \mathrm{G}$ tips 
however, it is of utmost importance to allow for estimating the fitness for purpose of currently employed sports drug testing methods.

\section{Qualitative method validation}

Main test method validation results for qualitative analytical purposes are summarized in Table 3. All target peptides were detected as 5-fold or 7-fold charged molecules and corresponding ions were observed at $\mathrm{m} / \mathrm{z} 672$ for Sermorelin and CJC-1293 ( $z=5)$, at $m / z 674$ for CJC$1295(z=5)$, at $\mathrm{m} / z 697$ for the ISTD $(z=5)$, and at $\mathrm{m} / z$ 734 for Tesamorelin $(z=7)$ as well as $m / z 625$ and 639 for the metabolites of Sermorelin $(z=5)$ and CJC-1293 $(z=5)$, respectively. The retention times of the analytes varied from 19.35 to 19.78 as depicted in Figs. 2 and 4. The specificity of the assay was demonstrated by the absence of interfering signals in defined extracted ion chromatograms of the analytes at expected retention times. Within the employed working range $(0.1-5 \mathrm{ng} / \mathrm{mL})$, the signal responses of all analytes proved linear with coefficients of correlation greater or equal to 0.994 . The sample preparation protocol as well as analytical setup were found to be compatible also with serum samples as assessed with a separate calibration curve experiment yielding coefficients of correlation $\geq 0.978$. Analyte recoveries concerning immunoaffinity purification were tested and varied between 19 and $37 \%$. The estimated LLOD of $50 \mathrm{pg} / \mathrm{mL}$ was corroborated with appropriate signal intensities and signal-to-noise ratios substantially greater than 3 for all target compounds as illustrated in Fig. 2. The imprecision of the method was determined as the relative standard deviation of the procedure for low $[50 \mathrm{pg} / \mathrm{mL}$, medium $[1 \mathrm{ng} / \mathrm{mL}]$, and high $[5 \mathrm{ng} / \mathrm{mL}]$ concentrations ranging from 3.5 to $19.2 \%$. Comparative spiking experiments between blank plasma samples and neat elution buffer for matrix effects showed no ion suppressing effects
[24-26]. On the contrary, higher signal intensities were observed for spiked plasma samples, an effect that was attributed to reduced unspecific losses of the analytes (e.g., on instrument or vial surfaces) in the presence of co-extracted plasma proteins.

\section{In vitro experiments}

Identifying potential metabolites of Sermorelin and Tesamorelin was accomplished by subtracting and comparing mass spectrometric full scan data of samples prepared before and after incubation of the substrates in fresh human plasma. For Tesamorelin, no degradation products of considerable abundance were detected, suggesting a substantial resistance towards proteolytic activities in human plasma. Conversely, in case of Sermorelin, the earlier reported metabolite $\left(\mathrm{GRF}_{3-29}\right)$ [7] was observed as a result of in vitro metabolic processes and the amounts of the intact drug decreased continuously with an increasing duration of incubation. After a period of $4 \mathrm{~h}$, Sermorelin was entirely degraded from the spiked plasma sample.

\section{In vivo experiments}

All intact GHRHs administered intravenously to rats were detected in plasma samples collected $2 \mathrm{~h}$ post dosing. In addition, Tesamorelin, CJC-1295, and CJC-1293 were also identified in specimens sampled 4 and $8 \mathrm{~h}$ post-administrating (Fig. 3), with the 8-h sample representing the latest collection time point of the study. Here it appears noteworthy that only qualitative results were obtained and that no pharmacokinetic interpretation was conducted. While all analytes were unequivocally identified and differentiated by mass spectrometry, chromatographic separation was accomplished for all target peptides with the exemption of the closely related compounds Sermorelin and CJC-1293 under the chosen analytical conditions. Both Sermorelin and CJC-1293, which differ only

Table 3 Main validation results for qualitative analysis of GHRHs in human plasma

\begin{tabular}{|c|c|c|c|c|c|c|}
\hline Parameter & & Sermorelin / CJC-1293 & CJC-1295 & Tesamorelin & $\begin{array}{l}\text { Sermorelin } \\
\text { metabolite }\end{array}$ & $\begin{array}{l}\text { CJC-1293 } \\
\text { metabolite }\end{array}$ \\
\hline LLOD [pg/mL] & & $<50$ & $<50$ & $<50$ & $<50$ & $<50$ \\
\hline Slope & & 13.157 & 13.099 & 6.735 & 6.432 & 8.000 \\
\hline Intercept & & -1.091 & -1.292 & -0.506 & -0.378 & -1.063 \\
\hline $\begin{array}{c}\text { Coefficient of } \\
\text { correlation }\end{array}$ & & 0.998 & 0.995 & 0.994 & 0.998 & 0.998 \\
\hline \multirow[t]{3}{*}{ Imprecision [\%] } & $50 \mathrm{pg} / \mathrm{mL}$ & 5.2 & 14.5 & 16.4 & 16.2 & 7.9 \\
\hline & $1 \mathrm{ng} / \mathrm{mL}$ & 7.6 & 5.4 & 3.5 & 8.4 & 6.8 \\
\hline & $5 \mathrm{ng} / \mathrm{mL}$ & 10.0 & 13.5 & 19.2 & 10.4 & 14.3 \\
\hline Recovery [\%] & & 23 & 19 & 37 & 27 & 30 \\
\hline
\end{tabular}



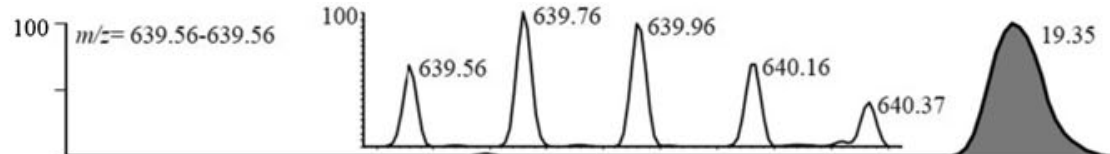

NL: 2.17E4

b

$100] \mathrm{m} / z=625.75-625.76$

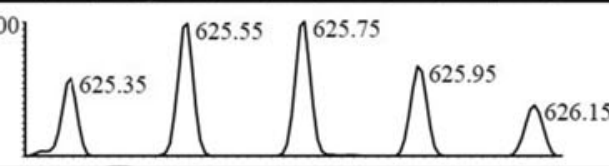

c
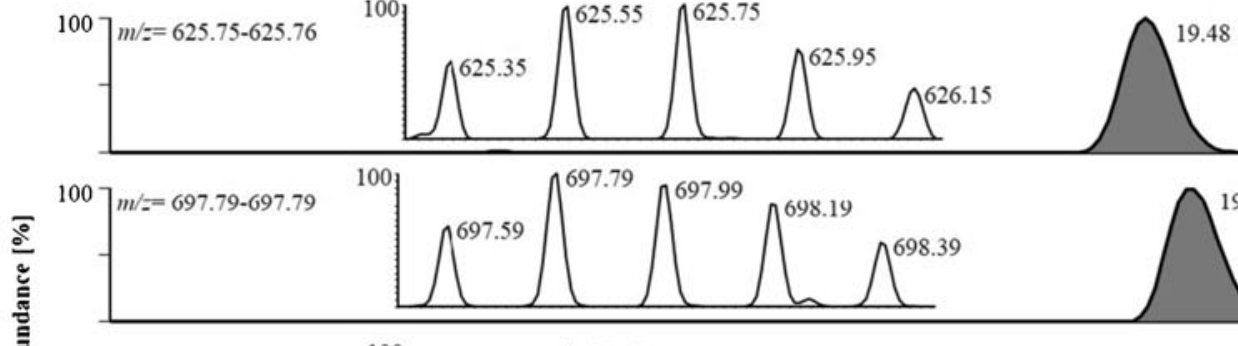

NL: 4.04E4

$1007 \mathrm{~m} / \mathrm{z}=672.37-672.38$
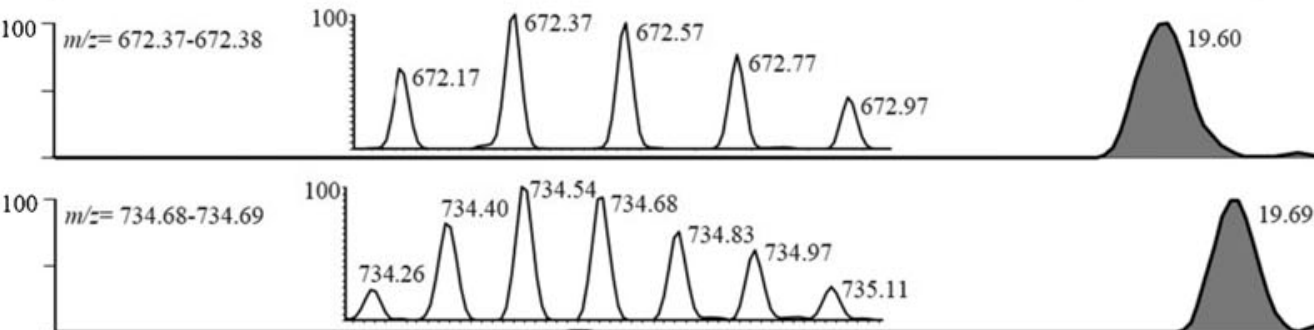

NL: $7.06 \mathrm{E} 4$

e
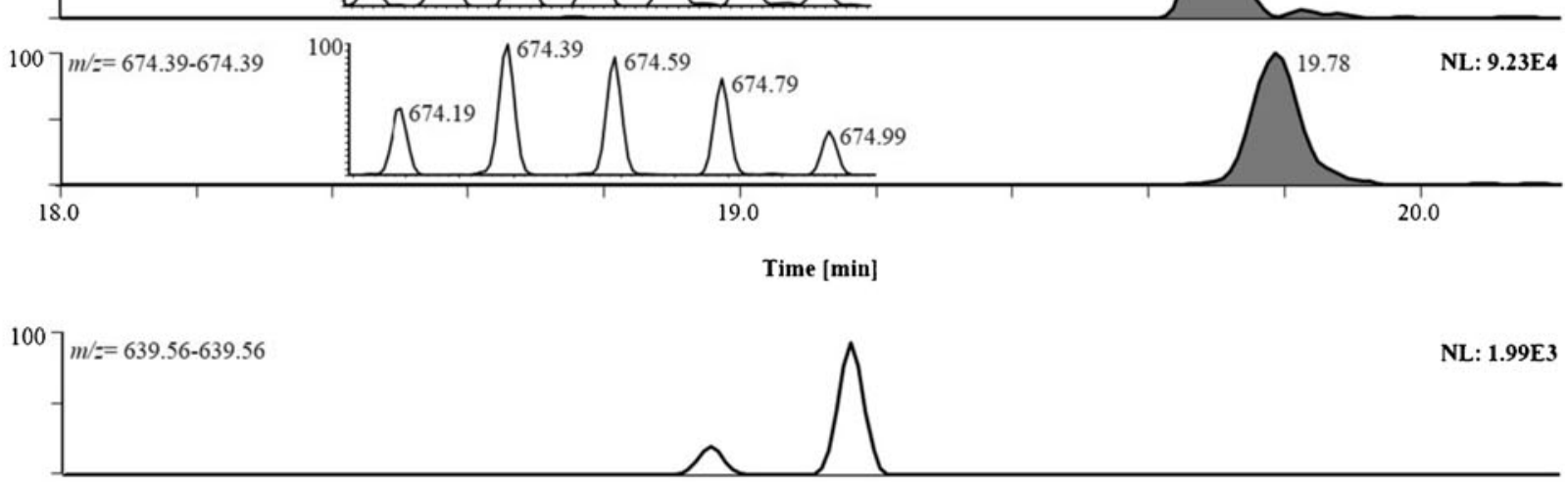

NL: $1.99 \mathrm{E} 3$

a

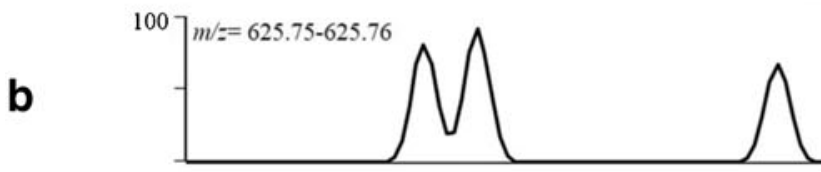

c

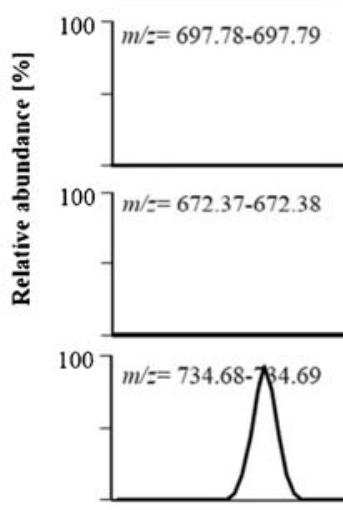

NL: $3.10 \mathrm{E} 4$

e

$1007 \mathrm{~m} /=674.39-674.39$

f

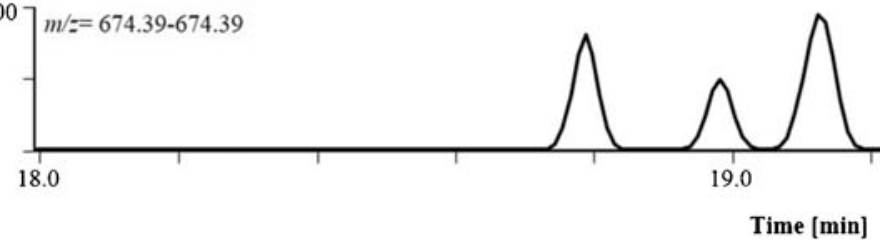

NL: $6.25 \mathrm{E} 2$ 
Fig. 2 Extracted ion chromatograms (targeted SIM experiments) of [a] a metabolite of CJC-1293, [b] a metabolite of Geref/Sermorelin, $[c]$ the ISTD, $[d]$ Geref/Sermorelin and CJC-1293, [e] Tesamorelin, and $[f]$ CJC-1295, all in human plasma. Corresponding high resolution mass spectra of the protonated molecules $[\mathrm{M}+5 \mathrm{H}]^{5+}$ and $[\mathrm{M}+7 \mathrm{H}]^{7+}$, respectively, are shown as insets. A spiked sample at the estimated LLOD of $50 \mathrm{pg} / \mathrm{mL}$ is shown as top panel and a corresponding blank plasma sample spiked with the ISTD only is presented below

by the substitution of $l$-alanine by $d$-alanine at position 2 (Table 1), were found to be readily biotransformed especially when compared to CJC-1295. However, none of the anticipated metabolic products such as $\mathrm{N}$ - or C-terminally truncated analogues were detected, suggesting the rapid and unspecific degradation of these compounds.

Compared to rat plasma samples collected after the intravenous application of Sermorelin, the human in vivo study (using subcutaneous drug application) indicates a different but also rapid metabolism of the peptide hormone. While the intact drug was not detected in any of the collected plasma samples, the in vitro-derived Sermorelin metabolite GRF $_{3-29}$ was detected in plasma $30 \mathrm{~min}$ post injection (Fig. 4). The subsequently collected specimen sampled after $90 \mathrm{~min}$ returned negative test results for the selected metabolite, suggesting the need for further metabolic products to allow for extended detection windows of the prohibited peptide hormone. In addition to EDTA plasma, also serum samples were collected at identical time points yielding comparable results (data not shown), which corroborated the possibility of using both matrices (i.e., serum and plasma) for doping control purposes.

In accordance to former GHRH pharmacokinetic studies by Jetté et al. [7], comparable metabolic stabilities of Sermorelin, CJC-1293, and CJC-1295 were observed. The results of the present assay confirm that Sermorelin is effectively metabolized and the $\mathrm{GRF}_{3-29}$ metabolite was found instead of the active substance in case of subcutaneous administration (to humans) as well as in vitro. Because of their D$\mathrm{Ala}^{2}$ modification, no analogous metabolites of CJC-1293 and

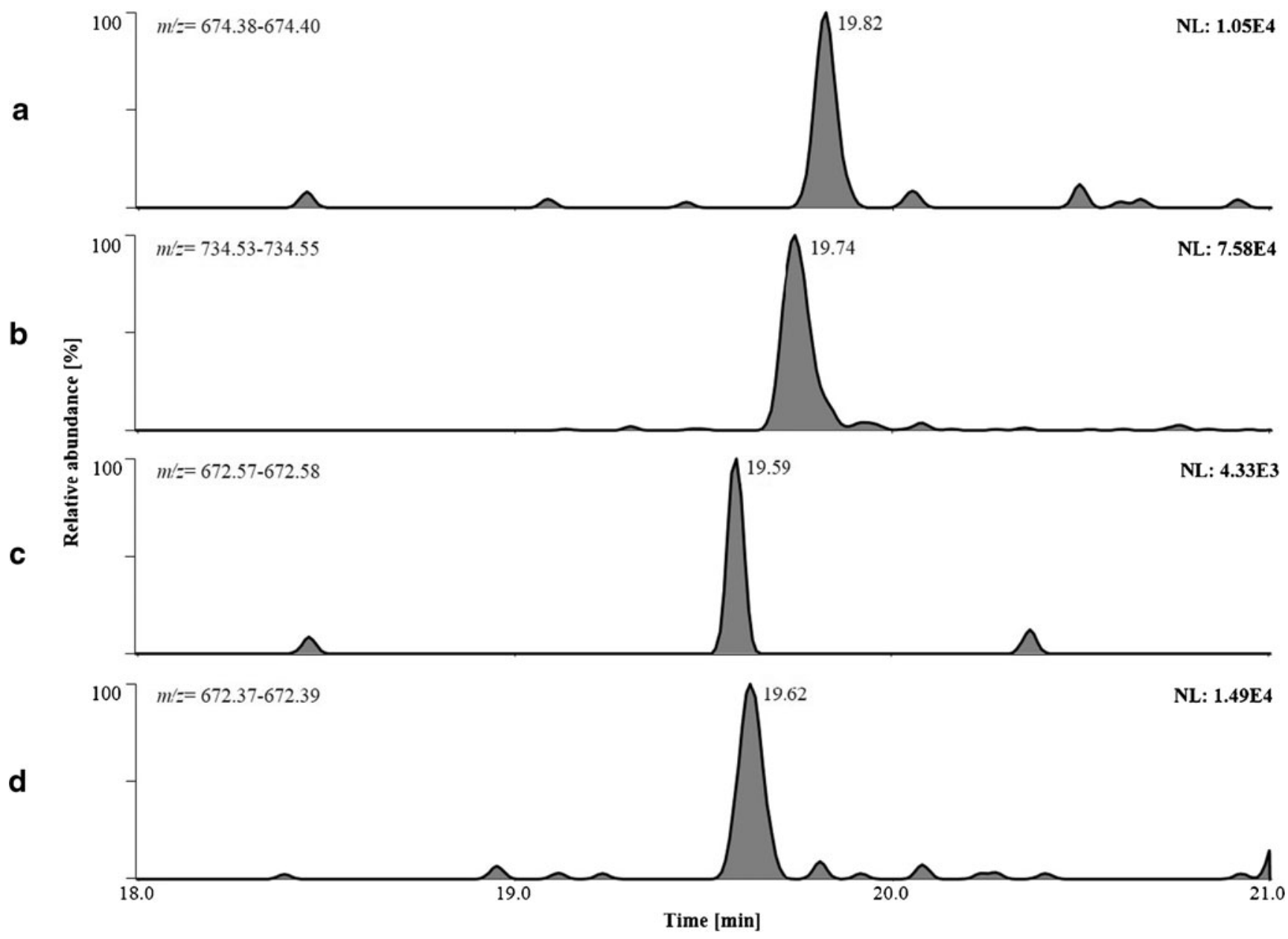

Fig. 3 Extracted ion chromatograms (targeted SIM experiments) of $[A]$ CJC-1295 (8 h post-administration), $[B]$ Tesamorelin $(8 \mathrm{~h}$ postadministration), [C] CJC-1293 (8 h post-administration), and $[D]$ Geref/
Sermorelin ( $2 \mathrm{~h}$ post-administration) in rat plasma after intravenous injection of $0.1 \mathrm{mg}$ of the drug 


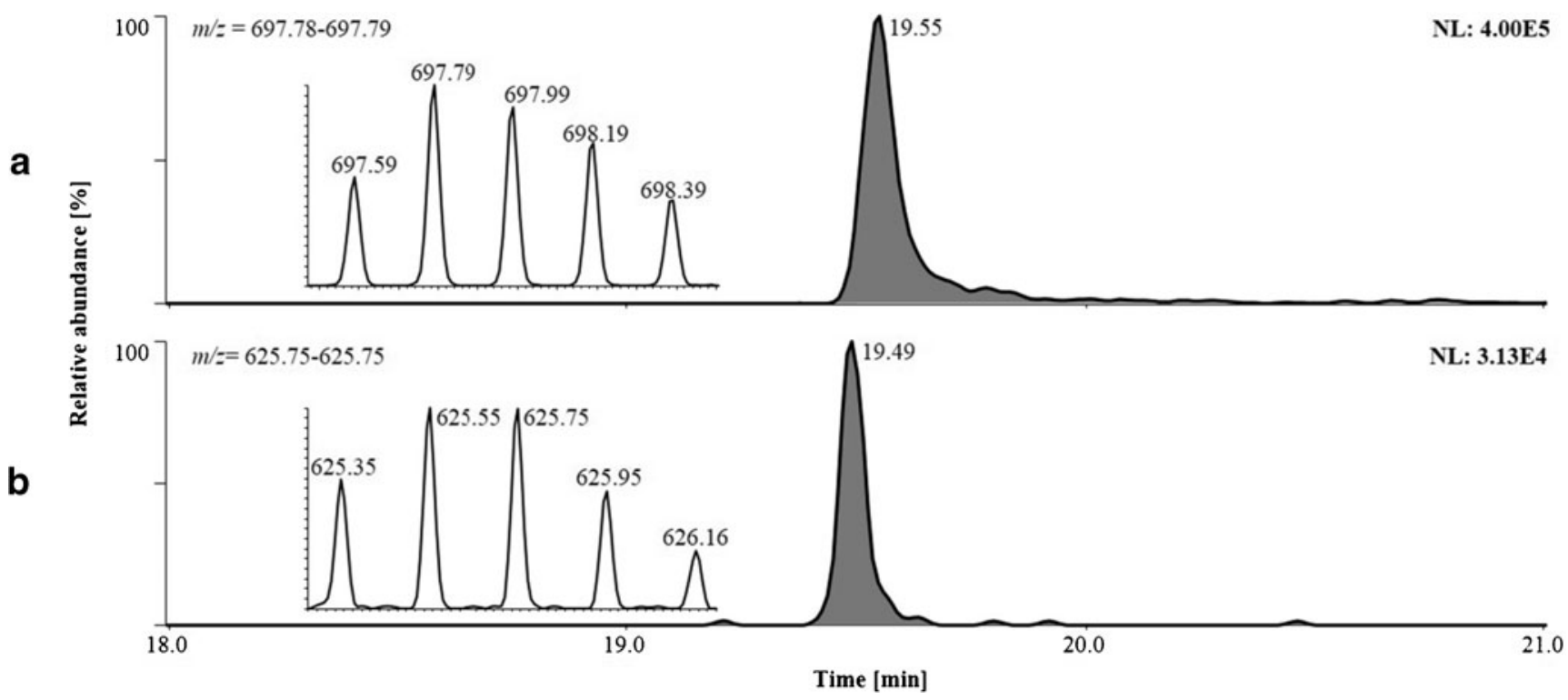

Fig. 4 Extracted ion chromatograms (targeted SIM experiments) of $[A]$ the ISTD and $[B]$ a Geref/Sermorelin metabolite in human plasma $30 \mathrm{~min}$ after subcutaneous application of $500 \mu \mathrm{g}$ of Geref/Sermorelin to a healthy

CJC-1295 were observed. Here, the intact compounds were detectable up to the latest sample collection time point and proved significantly longer-lasting, suggesting to include the administered substance in doping control analytical approaches. Similarly, the modified GHRH analogue Tesamorelin demonstrated considerable metabolic stability that enabled its identification at all sampling points (i.e., up to $8 \mathrm{~h}$ post-administration).

\section{Conclusion}

GHRHs are prohibited in elite sports at all times and, consequently, test methods are required that enable WADAaccredited laboratories to detect these analytes or respective metabolic products in routine doping control samples. In the light of the limited amount of information regarding the in vivo degradation of the GHRH-derived compounds Sermorelin, CJC-1293, CJC-1295, and Tesamorelin, both in vitro simulation as well as animal and human in vivo studies were conducted allowing to identify practical target analytes (i.e., intact compounds and/or diagnostic metabolites) to estimate detection windows and to establish and validate a test method utilizing a semi-automatable immunoaffinity purification (Protein A/G MSIA ${ }^{\mathrm{TM}}$ D.A.R.T.'S ${ }^{\circledR}$ ) approach followed by UHPLC-HR-MS(/MS) analysis. The developed assay was found to be fit for purpose, and the intact compounds and/or metabolites were detected for up to $8 \mathrm{~h}$ in administration study plasma samples. In case of Sermorelin, the detection window was limited to $2 \mathrm{~h}$ following a single dose application. These results suggest follow-up studies potentially enabling the male volunteer. Corresponding high-resolution mass spectra of the protonated molecules $[\mathrm{M}+5 \mathrm{H}]^{5+}$ are shown as insets

identification of additional metabolites offering extended detection windows.

Acknowledgments This project was supported in part by funding from the Partnership for Clean Competition Research Collaborative (grant \#R314). The content of this publication does not necessarily reflect the views or policies of the Research Collaborative. Further support was received from the World Anti-Doping Agency (grant \#14D04MT) and the Federal Ministry of the Interior of the Federal Republic of Germany (Berlin, Germany). The authors also thank Dr. Ravindra Chaudhari and Dr. Urban Kiernan (Thermo Fisher Scientific, Tempe, AZ) for providing the Finnpipette ${ }^{\mathrm{TM}}$ Novus i Multichannel Electronic Pipette.

Compliance with ethical standards All studies involving human participants were in accordance with the ethical standards of the institutional and/or national research committee and with the 1964 Helsinki declaration, its later amendments or comparable ethical standards, and written informed consent was obtained. Further, all applicable international, national, and/or institutional guidelines for the care and use of animals were followed.

Conflict of interest The authors have no conflicts of interest to declare.

Open Access This article is distributed under the terms of the Creative Commons Attribution 4.0 International License (http:// creativecommons.org/licenses/by/4.0/), which permits unrestricted use, distribution, and reproduction in any medium, provided you give appropriate credit to the original author(s) and the source, provide a link to the Creative Commons license, and indicate if changes were made.

\section{References}

1. Corpas E, Harman SM, Blackman MR. Human growth hormone and human aging. Endocr Rev. 1993;14(1):20-39. 
2. WADA Laboratory Committee. The 2015 Prohibited List. https:// wada-main-prod.s3.amazonaws.com/resources/files/wada-2015prohibited-list-en.pdf. Accessed 12 Oct 2015.

3. Ling N, Baird A, Wehrenberg WB, Ueno N, Munegumi T, Brazeau $\mathrm{P}$. Synthesis and in vitro bioactivity of C-terminal deleted analogs of human growth hormone-releasing factor. Biochem Biophys Res Commun. 1984;123(2):854-61.

4. Alba M, Fintini D, Sagazio A, Lawrence B, Castaigne JP, Frohman LA, et al. Once-daily administration of CJC-1295, a long-acting growth hormone-releasing hormone (GHRH) analog, normalizes growth in the GHRH knockout mouse. Am J Physiol Endocrinol Metab. 2006;291(6):E1290-4.

5. Boulanger L, Roughly P, Gaudreau P. Catabolism of rat growth hormone-releasing factor(1-29) amide in rat serum and liver. Peptides. 1992;13(4):681-9.

6. Ionescu M, Frohman LA. Pulsatile secretion of growth hormone (GH) persists during continuous stimulation by CJC-1295, a longacting GH-releasing hormone analog. J Clin Endocrinol Metab. 2006;91(12):4792-7.

7. Jetté L, Léger R, Thibaudeau K, Benquet C, Robitaille M, Pellerin I, et al. Human growth hormone-releasing factor (hGRF)1-29-albumin bioconjugates activate the GRF receptor on the anterior pituitary in rats: identification of CJC-1295 as a long-lasting GRF analog. Endocrinology. 2005;146(7):3052-8.

8. Khorram O, Laughlin GA, Yen SS. Endocrine and metabolic effects of long-term administration of [Nle27] growth hormone-releasing hormone-(1-29)-NH2 in age-advanced men and women. J Clin Endocrinol Metab. 1997;82(5):1472-9.

9. Sackmann-Sala L, Ding J, Frohman LA, Kopchick JJ. Activation of the GH/IGF-1 axis by CJC-1295, a long-acting GHRH analog, results in serum protein profile changes in normal adult subjects. Growth Hormon IGF Res. 2009;19(6):471-7.

10. Teichman SL, Neale A, Lawrence B, Gagnon C, Castaigne JP, Frohman LA. Prolonged stimulation of growth hormone (GH) and insulin-like growth factor I secretion by CJC-1295, a longacting analog of GH-releasing hormone, in healthy adults. J Clin Endocrinol Metab. 2006;91(3):799-805.

11. Kwok WH, Ho EN, Lau MY, Leung GN, Wong AS, Wan TS. Doping control analysis of seven bioactive peptides in horse plasma by liquid chromatography-mass spectrometry. Anal Bioanal Chem. 2013;405(8):2595-606.

12. Henninge J, Pepaj M, Hullstein I, Hemmersbach P. Identification of CJC-1295, a growth-hormone-releasing peptide, in an unknown pharmaceutical preparation. Drug Test Anal. 2010;2(11-12):647-50.

13. Esposito S, Deventer K, Van Eenoo P. Identification of the growth hormone-releasing hormone analogue [Pro1, Val14]-hGHRH with an incomplete C-term amidation in a confiscated product. Drug Test Anal. 2014;6(11-12):1155-9.

14. Lopez MF, Rezai T, Sarracino DA, Prakash A, Krastins B, Athanas $\mathrm{M}$, et al. Selected reaction monitoring-mass spectrometric immunoassay responsive to parathyroid hormone and related variants. Clin Chem. 2010;56(2):281-90.

15. Parker CE, Pearson TW, Anderson NL, Borchers CH. Massspectrometry-based clinical proteomics - a review and prospective. Analyst. 2010;135(8):1830-8.

16. Nelson RW, Krone JR, Bieber AL, Williams P. Mass spectrometric immunoassay. Anal Chem. 1995;67(7):1153-8.

17. Thomas A, Delahaut P, Krug O, Schänzer W, Thevis M. Metabolism of growth hormone releasing peptides. Anal Chem. 2012;84(23):10252-9.

18. Thomas A, Schänzer W, Delahaut P, Thevis M. Sensitive and fast identification of urinary human, synthetic and animal insulin by means of nano-UPLC coupled with high-resolution/high-accuracy mass spectrometry. Drug Test Anal. 2009;1(5):219-27.

19. Thomas A, Schänzer W, Delahaut P, Thevis M. Immunoaffinity purification of peptide hormones prior to liquid chromatographymass spectrometry in doping controls. Methods. 2012;56(2):230-5.

20. Thomas A, Walpurgis K, Tretzel L, Brinkkötter P, Fichant E, Delahaut $\mathrm{P}$, et al. Expanded test method for peptides $>2 \mathrm{kDa}$ employing immunoaffinity purification and LC-HRMS/MS. Drug Test Anal. 2015.

21. Smits NG, Blokland MH, Wubs KL, Nessen MA, van Ginkel LA, Nielen MW. Monolith immuno-affinity enrichment liquid chromatography tandem mass spectrometry for quantitative protein analysis of recombinant bovine somatotropin in serum. Anal Bioanal Chem. 2015;407(20):6041-50.

22. Werle M, Bernkop-Schnürch A. Strategies to improve plasma half life time of peptide and protein drugs. Amino Acids. 2006;30(4): 351-67.

23. Thomas A, Brinkkötter P, Schänzer W, Thevis M. Metabolism of human insulin after subcutaneous administration: a possible means to uncover insulin misuse. Anal Chim Acta. 2015;897:53-61.

24. Trufelli H, Palma P, Famiglini G, Cappiello A. An overview of matrix effects in liquid chromatography-mass spectrometry. Mass Spectrom Rev. 2011;30(3):491-509.

25. Furey A, Moriarty M, Bane V, Kinsella B, Lehane M. Ion suppression; a critical review on causes, evaluation, prevention and applications. Talanta. 2013;115:104-22.

26. Matuszewski BK, Constanzer ML, Chavez-Eng CM. Strategies for the assessment of matrix effect in quantitative bioanalytical methods based on HPLC-MS/MS. Anal Chem. 2003;75(13): 3019-30. 